\title{
Evaluation of genotoxicity by comet assay (single-cell gel electrophoresis) in tissues of the fish Cyprinus carpio during sub-lethal exposure to Karanjin
}

\author{
Shoeiba Tasneem ${ }^{*}$ and Rafath Yasmeen
}

\begin{abstract}
Background: Adverse effects caused by the synthetic pesticides has forced scientists to develop an alternative against the synthetic pesticides. Therefore, it has come a boon to mankind in the form of neem tree having secondary metabolites showing pesticidal properties which is in use since many years. Like neem tree, there has been research done on karanja plant, and its secondary metabolite karanjin has been found to possess good pesticidal properties. Comet assay or alkaline single-cell gel electrophoresis (SCG) was performed in fish Cyprinus carpio after exposure to sub-lethal concentration $(0.28 \mathrm{ppm})$ of karanjin. The assay was carried out in the gill, liver, kidney, and blood. The total DNA content in each tissue was also estimated using Nano Drop.

Results: The present study clearly shows that though karanjin is a derived secondary metabolite from plant, it is capable of producing genotoxicity in common carp. As the days of sub-lethal exposure increased, all the four tissues showed decrease in total DNA content which was directly proportional to the formation of DNA comet tails.
\end{abstract}

Conclusion: The use of any kind of plant metabolites in the agriculture and aquaculture farms should be monitored well.

Keywords: Gill, Liver, Kidney, Blood, SCGE, Common carp

\section{Background}

The human populations around the globe have faced many problems and also harmful health effects due to the residual effects of synthetic pesticides. Since the past few decades, many scientists have done a lot of research in searching and formulating an alternative for the synthetic pesticides. A big problem of humans has been solved by the discovery of plants possessing natural insecticidal components (Lopez, Jordan, \& Pascual-Villalobos, 2008; Pavela, 2009; Kim et al., 2010). Plants are the inexhaustible sources of structurally diverse and biologically active substances having medicinal and pesticidal properties (Istvan, 2000). There are many plant species available throughout the world. Different plant parts such as leaves,

\footnotetext{
* Correspondence: shoeiba.tas@gmail.com

Department of Zoology, University College of Science, Osmania University, Hyderabad, Telangana State 500007, India
}

seeds, bark, and stem are being used either in the crude form or as active ingredients which are being isolated and being used as pesticides (Karunamoorthi, 2012).

Neem tree is known since ancient times to have medicinal and pesticidal properties. Every part of neem tree contains various classes of active ingredients that have insecticidal properties, piscicidal properties, and molluscicidal properties. Various parts of neem tree have been used in many countries as insecticides and insect repellents apart from many other medicinal uses (WHO, 2003). The active ingredient which has been isolated from the seeds of neem is azadirachtin, and it has been used since many years in the manufacture of many neem-based pesticides with different concentrations and different names (Anis Joseph, Premila, Nisha, Rajendran, \& Sarika Mohan, 2010; Vethanayagam \& Rajendran, 2010). We have an assumption that as these active 


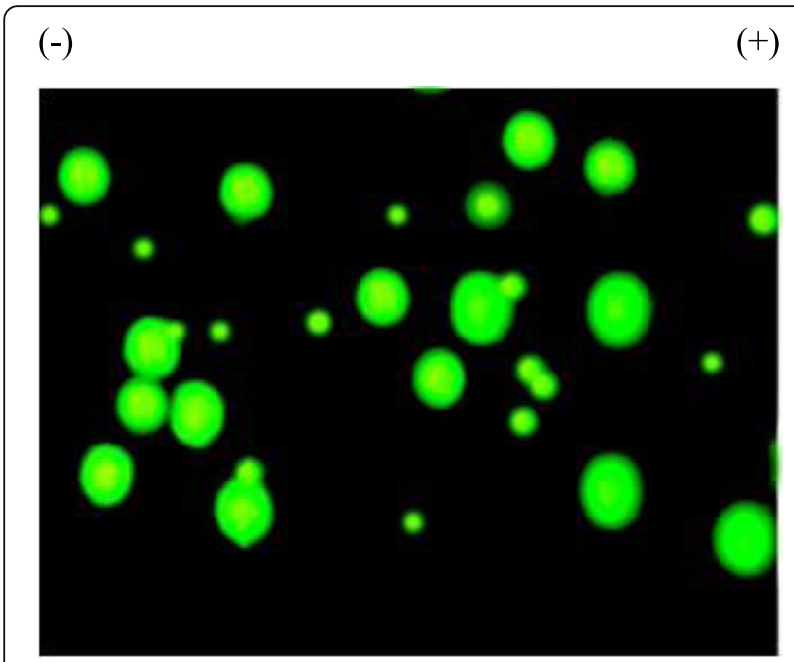

Fig. 1 Type 0 DNA damage

metabolites are synthesized and isolated from plants, they are very safe and not having any impact on other non-target organisms. Recently, it was found that a neem-based pesticide, with brand name Achook, was toxic to zebrafish Danio rerio (Ansari \& Sharma, 2009).

Not only neem tree but there are a thousand many more trees having active components possessing pesticidal properties. One more plant species that has gained attention and interest to scientists is the Pongamia pinnata, also known as Derris indica, commonly known as karanj plant. One of the most important active ingredients isolated from the seeds of this plant is a flavonoid called karanjin. This active ingredient is being used in the manufacturing of biopesticides and bioinsecticides in different names, one of them being Derisom (Majumdar, 2002; Majumdar, Pandya,

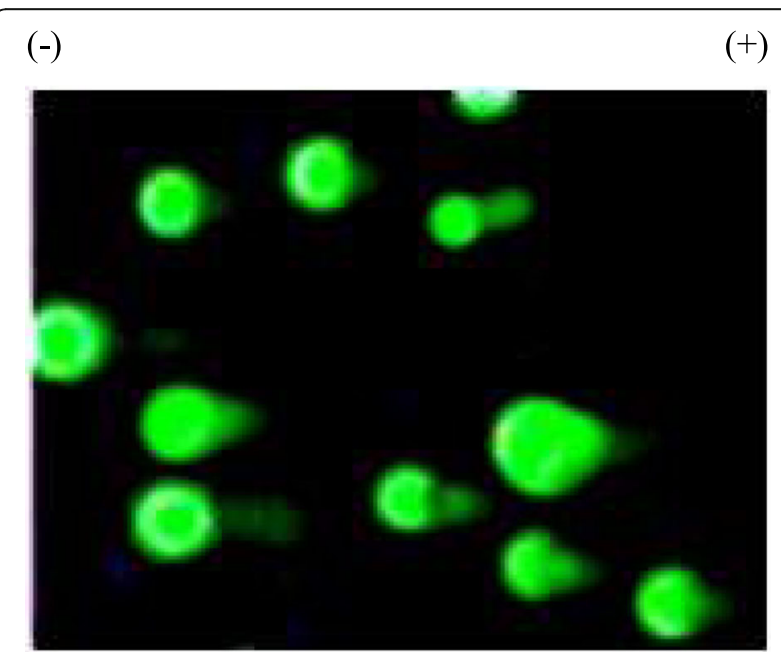

Fig. 2 Type I DNA damage
$(-)$

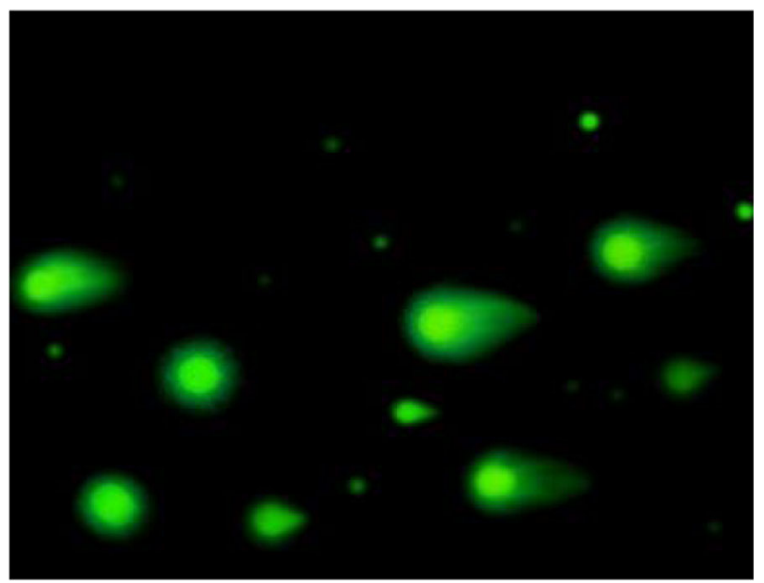

Fig. 3 Type II DNA damage

Arora, \& Dhara, 2004; Tamrakar, Yadav, Tiwari, Maurya, \& Srivastava, 2008; Al Muqarrabun, Ahmat, Ruzaina, Ismail, \& Sahidin, 2013). The seeds of Pongamia pinnata have an additional important benefit along with its possessing pesticidal properties, and the seeds are also being used for the synthesis of biodiesel along with the famous plant Jatropha. Hence, Pongamia pinnata can be considered as a boon to mankind next to neem tree.

Comet assay or alkaline single-cell gel electrophoresis (SCGE) is a very simple, fast, and sensitive technique for assessing genotoxicity by quantifying the amount of DNA damage caused in individual cells. It is used as an important tool for environmental monitoring and assessing health of aquatic animals by detecting DNA damage in fish, clams,

$(-)$

$(+)$

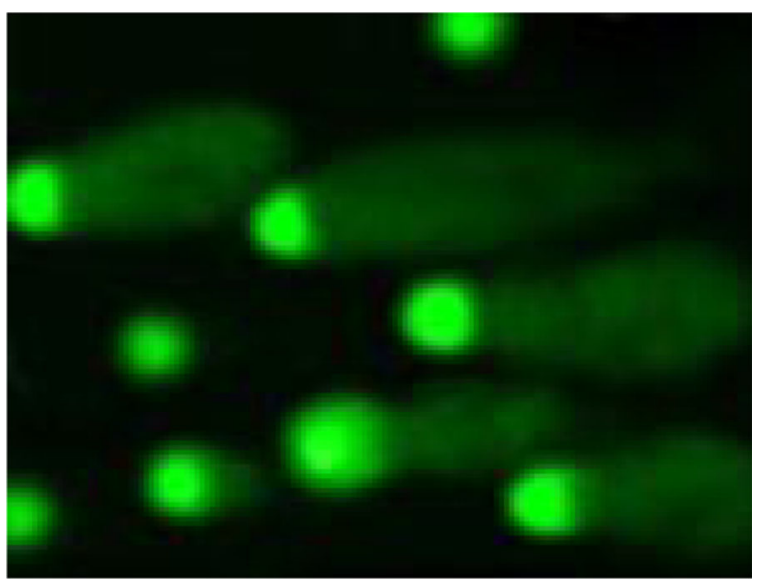

Fig. 4 Type III DNA damage 


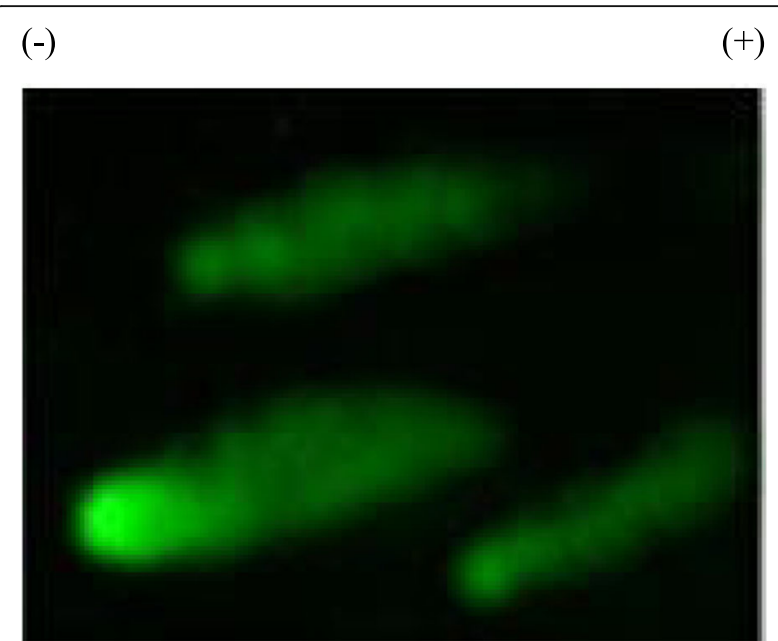

Fig. 5 Type IV DNA damage

shellfish, and mussels (Andrade, Freitas, \& Silva, 2004; Belpaeme, Delbeke, Zhu, \& Kirsch-Volders, 2004). Comet assay is used to detect genetic damage in the form of DNA strand break, which is an additional sensitive indicator. This assay has been applied in aquatic environments to assess and monitor the health and genetic condition of both vertebrate and invertebrate organisms (Kleinjans \& Van Schooten, 2002). In vivo data on fish were obtained with redbreast sunfish (Lepomis auritus), hard head cat fish (Anus felis), bullhead (Ameirurus nebulosus), and carp (C. carpio) to see if there was any kind of genetic damage in tissues of fish in aquatic environment due to pollutants (Mitchelmore \& Chipman, 1998). Comet assay studies have also been performed in Cyprinus carpio exposer in vitro to heavy metal nickel and lead (Mitkovska, Dimitrov, \& Chassovnikarova, 2017). DNA damage studies have been performed in different fish species collected from upper and middle stretches of Adige river basin (Kracun-Kolarevic et al., 2016).

The fish used in the present study is the common carp-Cyprinus carpio. It is the second largest fish consumed next to Indian major carps. The fish has high growth rate, has easy adaptability to lab conditions, and easily feeds on artificial feed; hence, it has been selected for the research purpose. Till date, no other researcher
Table 2 Nucleoids in various damage degrees in the liver of $C$. carpio on exposure to karanjin

\begin{tabular}{llllll}
\hline Exposure & Type 0 & Type I & Type II & Type III & Type IV \\
\hline Control & $87 \pm 1.41$ & $8.33 \pm 1.5$ & $4.3 \pm 1.03$ & 0 & 0 \\
$24 \mathrm{~h}$ & $80.33 \pm 2.58$ & $8.5 \pm 1.04$ & $11.16 \pm 1.16$ & 0 & 0 \\
7 days & $74 \pm 2.6$ & $4.8 \pm 1.47$ & $10 \pm 2.09$ & $8.16 \pm 1.16$ & $3.16 \pm 1.16$ \\
14 days & $63 \pm 2.6$ & $4.5 \pm 1.04$ & $6.5 \pm 1.04$ & $12.66 \pm 1.63$ & $13.5 \pm 1.04$ \\
21 days & $52.66 \pm 2.80$ & $3.16 \pm 1.16$ & $8.66 \pm 1.75$ & $16 \pm 2.60$ & $19.66 \pm 2.16$
\end{tabular}

One hundred cells are evaluated. Values are expressed as mean \pm standard deviation

has worked on the toxicity and genotoxicity effects of karanjin on C. carpio or any other fish species. Hence, the aim of the study was to evaluate the DNA damage in tissues of fish, C. carpio, on exposure to karanjin.

\section{Methods}

\section{Source of karanjin}

Karanjin is a furano-flavonoid isolated from the seeds of Pongamia pinnata also known as Derris indica. Karanjin has been proven to have pesticidal properties. The source of karanjin is "Derisom" which is a biopesticide in liquid formulation having karanjin and karanjin oil as active ingredients dissolved in solvents (butanol and butyl acetate) and emulsifier which are inactive. The source of karanjin, Derisom, was procured from the manufacturer Agri Life India Private Limited, IDA, Bollaram, Hyderabad. The acute toxicity or 96-h lethal concentration (LC) 50 value of karanjin-based biopesticide Derisom to the common carp Cyprinus carpio was already determined by Finney's probit analysis method.

\section{Experimental animal}

Juveniles of Cyprinus carpio ranging in length $14 \pm$ $0.83 \mathrm{~cm}$ and weighing $38.53 \pm 1.79 \mathrm{~g}$ were collected from Kaikaluru village of Andhra Pradesh State and transported to the laboratory in a well-aerated condition. The fishes were acclimatized in well-aerated tanks for a period of 1 month. They were fed twice daily with commercially available fish feed pellets, and the water was renewed daily. The 96-h LC50 value of karanjin (Derisom) was already estimated as $2.8 \mathrm{ppm} 1 / 10$ th of the $96-\mathrm{h}$ LC50 value, i.e., $0.28 \mathrm{ppm}$ concentration taken
Table 1 Nucleoids in various damage degrees in the gill of $C$. carpio on exposure to karanjin

\begin{tabular}{llllll}
\hline Exposure & Type 0 & Type I & Type II & Type III & Type IV \\
\hline Control & $86.5 \pm 3.27$ & $9.66 \pm 1.03$ & $4 \pm 0.89$ & 0 & 0 \\
$24 \mathrm{~h}$ & $74.16 \pm 3.06$ & $18.66 \pm 3.38$ & $7.33 \pm 1.86$ & 0 & 0 \\
7 days & $66.33 \pm 2.16$ & $8.16 \pm 1.47$ & $12.5 \pm 1.87$ & $9.5 \pm 1.87$ & $3.66 \pm 2.16$ \\
14 days & $54.33 \pm 2.80$ & $6.5 \pm 1.04$ & $10.66 \pm 1.21$ & $17 \pm 2.36$ & $11.5 \pm 2.42$ \\
21 days & $50.16 \pm 2.40$ & $3.83 \pm 1.47$ & $7.83 \pm 2.13$ & $20.83 \pm 1.47$ & $17.5 \pm 1.87$ \\
\hline
\end{tabular}

One hundred cells are evaluated. Values are expressed as mean \pm standard deviation
Table 3 Nucleoids in various damage degrees in the kidney of C. carpio on exposure to karanjin

\begin{tabular}{llllll}
\hline Exposure & Type 0 & Type I & Type II & Type III & Type IV \\
\hline Control & $88.16 \pm 1.47$ & $7.33 \pm 1.96$ & $5.16 \pm 1.72$ & 0 & 0 \\
$24 \mathrm{~h}$ & $77.5 \pm 2.42$ & $13.5 \pm 1.87$ & $9.33 \pm 1.50$ & 0 & 0 \\
7 days & $67.83 \pm 2.13$ & $8.16 \pm 1.47$ & $6.16 \pm 1.16$ & $15.16 \pm 1.47$ & $2.83 \pm 0.75$ \\
14 days & $60.16 \pm 1.16$ & $9.5 \pm 1.04$ & $7.66 \pm 1.63$ & $14.16 \pm 1.16$ & $8.83 \pm 1.16$ \\
21 days & $53.5 \pm 2.16$ & $7.83 \pm 1.47$ & $11.16 \pm 1.16$ & $13.16 \pm 1.16$ & $14.66 \pm 1.75$ \\
\hline
\end{tabular}

One hundred cells are evaluated. Values are expressed as mean \pm standard deviation 
Table 4 Nucleoids in various damage degrees in the blood of C. carpio on exposure to karanjin

\begin{tabular}{llllll}
\hline Exposure & Type 0 & Type I & Type II & Type III & Type IV \\
\hline Control & $89.5 \pm 3.08$ & $6.83 \pm 1.47$ & $3.83 \pm 1.47$ & 0 & 0 \\
$24 \mathrm{~h}$ & $80.83 \pm 1.47$ & $7.66 \pm 1.36$ & $11.5 \pm 1.87$ & 0 & 0 \\
7 days & $69.83 \pm 2.31$ & $6.5 \pm 1.04$ & $8.66 \pm 1.96$ & $9.66 \pm 1.36$ & $5.5 \pm 1.87$ \\
14 days & $60.5 \pm 3.08$ & $5.83 \pm 1.47$ & $10.33 \pm 1.86$ & $13.33 \pm 2.25$ & $10.16 \pm 1.47$ \\
21 days & $51 \pm 2.09$ & $4.16 \pm 1.16$ & $9.5 \pm 1.04$ & $16.33 \pm 2.25$ & $19.16 \pm 2.13$ \\
\hline
\end{tabular}

One hundred cells are evaluated. Values are expressed as mean \pm standard deviation

as the sub-lethal value. The fish were exposed to the sub-lethal concentration for a period of 21 days. After the completion of $24 \mathrm{~h}, 7$ days, 14 days, and 21 days, the blood was drawn through caudal vein puncture from both control and exposed group fishes and the blood was transferred into EDTA coated tubes, an equal amount of chilled phosphate buffer was added, and centrifuged at $5000 \mathrm{rpm}$ for $15 \mathrm{~min}$, and the supernatant was discarded and the pellet was stored in a $-20{ }^{\circ} \mathrm{C}$ refrigerator till further analysis was done. The organs gill, liver and kidney were dissected from the fishes of both control and exposed groups, washed in saline, and transferred to tubes containing phosphate buffer.

\section{Protocol for comet assay}

The alkaline comet assay was performed according to Tice et al. (2000), as modified by Hartman et al. (2004) and Lemos, Dias, Silva-Souza, \& Mantovani (2005). Cells are combined at $1 \times 10^{5} / \mathrm{ml}$ with molten low-melting agarose (LM Agarose) (at $37^{\circ} \mathrm{C}$ ) at a ratio of $1: 10(\mathrm{v} / \mathrm{v})$, and immediately, $50 \mu \mathrm{l}$ of it is pipetted out onto a comet slide which was placed on a flat surface at $4{ }^{\circ} \mathrm{C}$ in the dark for $10 \mathrm{~min}$. The slides (coated with LM Agarose and cell suspension) were immersed in a lysis buffer solution (2.5 M NaCl, $100 \mathrm{mM}$ EDTA, and $10 \mathrm{mM}$ Trizma base) at $4{ }^{\circ} \mathrm{C}$ for $30-60 \mathrm{~min}$. The comet slides were immersed in freshly prepared alkaline unwinding solution (300 mM NaOH/1 mM EDTA), $\mathrm{pH}>13$ for $20 \mathrm{~min}$ at room temperature. The slides were placed in the electrophoresis slide tray and covered with a slide tray overlay. The power supply was set at $21 \mathrm{~V}$, and the voltage was applied for $30 \mathrm{~min}$. The samples were dried at $37{ }^{\circ} \mathrm{C}$ for $10-15 \mathrm{~min}$. The samples were stored at room temperature, with desiccant (commonly used desiccant is silica gel) prior to scoring. One hundred microliters of diluted SYBER Green dye was placed onto each circle of dried agarose and stained for $30 \mathrm{~min}$ at room temperature in the dark. They were finally allowed to dry completely at $37^{\circ} \mathrm{C}$, viewed, observed thoroughly by a fluorescence microscope (Carl Zeiss, Germany), and photographed.

\section{Extraction of DNA from the gill, liver, kidney, and blood of C. carpio}

Fresh tissues from individual fish were taken and DNA was extracted using a DNeasy Qiagen kit, following the tissue and blood extraction protocol provided along with the kit. Twenty-five milligrams of tissue of the gill, liver, and kidney and $10 \mu \mathrm{l}$ of the blood were collected. One hundred eighty microliters of buffer ATL was added to each of the tube of the gill, liver, and kidney. To each tube, $20 \mu \mathrm{l}$ of proteinase $\mathrm{K}$ was added in order to obtain the lysed tissue. Two hundred microliters of buffer AL was added to all tubes and mixed thoroughly by vortexing. Later, $200 \mu \mathrm{l}$ of ethanol (96-100\%) was added to the tubes and mixed again thoroughly by vortexing. The tubes were centrifuged at $8000 \mathrm{rpm}$ for $1 \mathrm{~min}$. Five hundred microliters of buffer AW1 was added and centrifuged for $1 \mathrm{~min}$ at $8000 \mathrm{rpm}$. Five hundred microliters of buffer AW2 was added and centrifuged for $3 \mathrm{~min}$ at $14,000 \mathrm{rpm}$ to dry the DNeasy membrane. Two hundred microliters of buffer AE was pipetted out directly onto the DNeasy membrane, incubated at room temperature for $1 \mathrm{~min}$, and centrifuged for $1 \mathrm{~min}$ at $8000 \mathrm{rpm}$ for the DNA to elute.

\section{Electrophoresis of the extracted DNA}

The purity of the extracted DNA was estimated using agarose gel electrophoresis (Salem et al., 2014). The DNA obtained was subjected to electrophoresis at $100 \mathrm{~V}$ on $1.2 \%$ agarose gel with Tris-borate-EDTA buffer

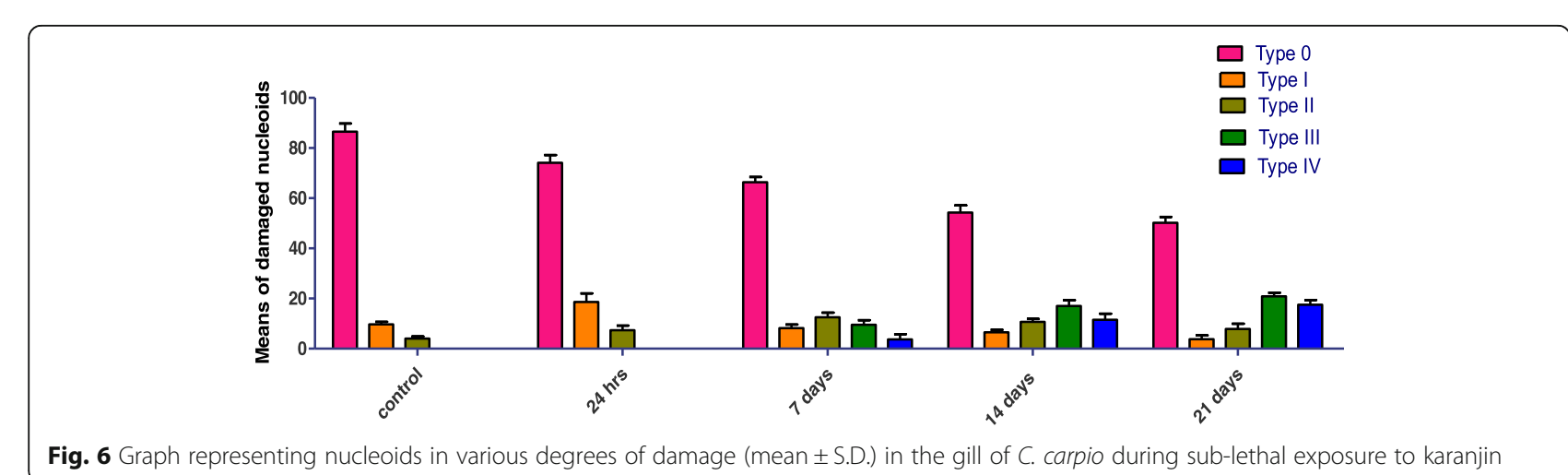




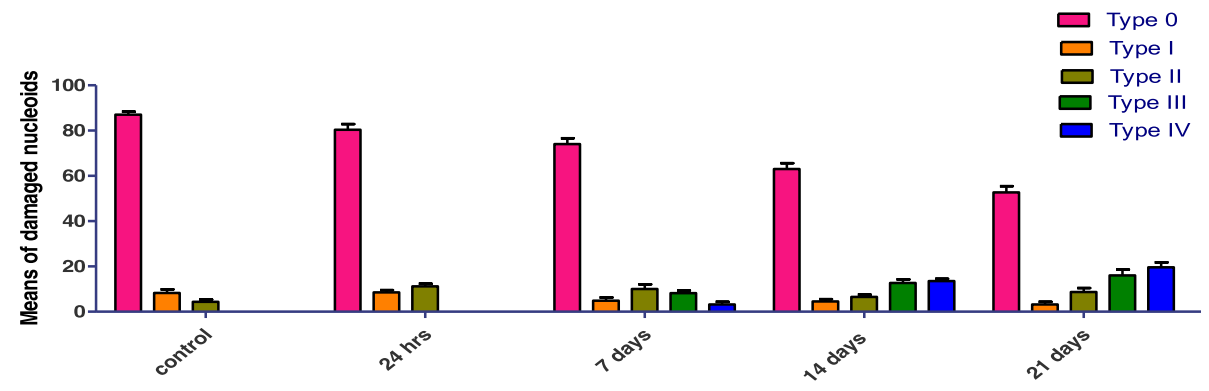

Fig. 7 Graph representing nucleoids in various degrees of damage (mean \pm S.D.) in the liver of C. carpio during sub-lethal exposure to karanjin

(Sambrook, Fritsch, \& Maniatis, 1989). The gel was placed into the tank. EtBr was added to the $900 \mathrm{ml}$ of $0.5 \times \mathrm{TBE}(45 \mu \mathrm{l}$ of a $10 \mathrm{mg} / \mathrm{ml}$ stock solution). The buffer was poured into the tank covering the gel. One microliter of loading dye was added per 5- $\mu$ l sample. Samples were then loaded into the wells. The tank was connected to power supply-voltage at $\sim 100 \mathrm{~V}$. The power is supplied for about an hour. The gel was imaged using gel doc instrument to visualize the DNA bands under UV light. The gel was carried in the casting tray and transferred onto the trans-illuminator. The UV light was turned on to $100 \%$. The DNA bands were visible and the images were captured by the camera provided along with the gel doc instrument, and the image was saved for further analysis.

\section{Quantification of extracted DNA using Nano Drop}

The concentration of the extracted DNA in the tissue samples of both control and exposed groups was estimated using Nano Drop ND-1000 Spectrophotometer (Thermo Scientific, Wilmington, Delaware, USA) (Salem et al., 2014). Nano Drop is a very efficient and easy to use instrument, which requires very less amount of sample to be measured, i.e., it requires only $2 \mu \mathrm{l}$ of DNA sample. Nano Drop uses a wavelength of $260 / 280 \mathrm{~nm}$ to measure the amount of DNA in the given sample. The values were expressed as nanograms per microliter of sample.

\section{Statistical analysis}

All the results obtained were subjected to statistical analysis using IBM SPSS software version 21 using one-way ANOVA along with post hoc LSD test. All the results are presented as mean \pm standard deviation at $P<0.05$ level of significance. The graph was made using GraphPad Prism software version 5.

\section{Results}

For each exposed and control group, a total of hundred comets were scored visually (50/slide and 2 slides/fish). The cells were categorized into five classes based on the presence of tail and the intensity of tail length. The cells having no DNA damage showed the presence of intact nuclei, and these were as follows: the first class cells of were the type 0 (no DNA damage) (Fig. 1), the second class of cells were the type I (mild DNA damage) (Fig. 2), the third class of cells were the type II (moderate DNA damage) (Fig. 3), the fourth class of cells were the type III (high DNA damage) (Fig. 4), and the fifth class of

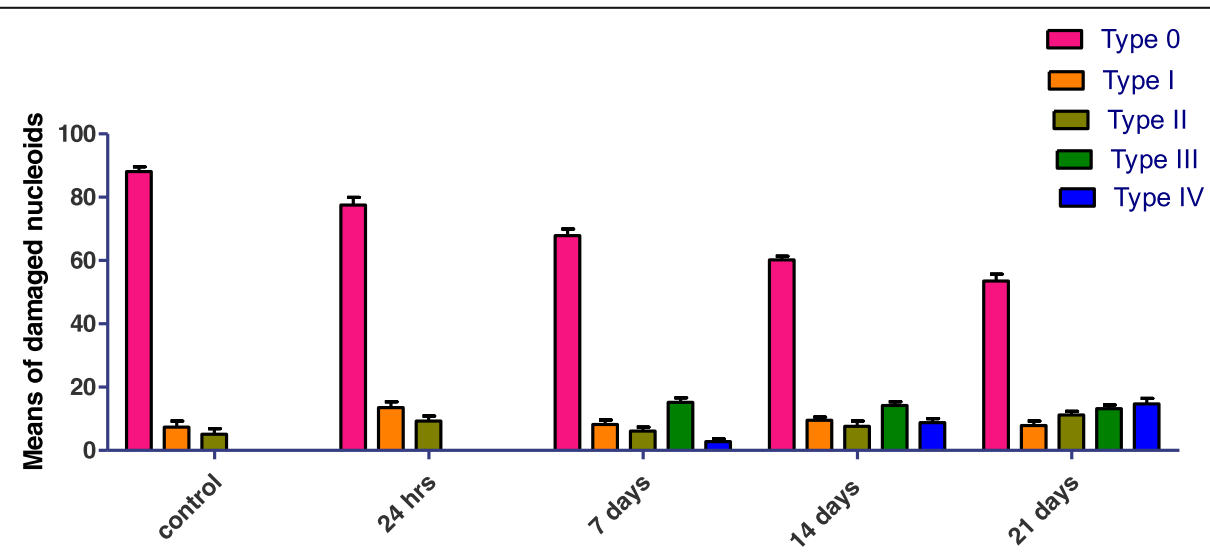

Fig. 8 Graph representing nucleoids in various degrees of damage (mean \pm S.D.) in the kidney of C. carpio during sub-lethal exposure to karanjin 


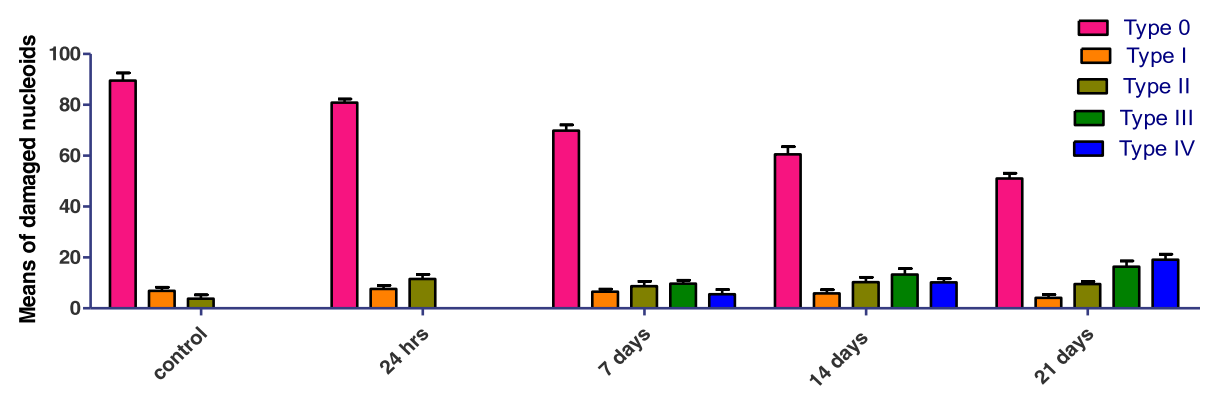

Fig. 9 Graph representing nucleoids in various degrees of damage (mean \pm S.D.) in the blood of C. carpio during sub-lethal exposure to karanjin

cells were the type IV (extensive DNA damage) (Fig. 5). The classes of DNA damage type 0 to type IV were given by Anderson, Yu, Phillips, and Schezer (1994) (Tables 1, 2, 3, and 4). This method of comet scoring gives us a quantifiable resolution which is useful for many purposes (Liao, McNutt, \& Zhu, 2009). The amount of DNA migrated as comet tail of various lengths was known as DNA damage (Grover et al., 2003). The DNA damage was evaluated as percent of damage cells (taking into account only the cells of type II, type III, and type IV) as given by Palus, Dziubaltowska, and Rydzynski (1999) and genetic damage index (GDI) as described by Collins (2004) and Pitarque, Creus, Marcos, Hughes, and Anderson (1999). The genetic damage index was calculated by using the formula:

$$
\text { GDI }=\frac{1 . \text { Type } 1+2 . \text { Type II }+3 . \text { Type III }+4 . \text { Type IV }}{\text { Type } 0+\text { I }+ \text { II }+ \text { III }+ \text { IV }}
$$

The tissues gill, liver, kidney, and blood showed the presence of maximum number of only type 0 and type I nucleoids in the control group (Figs. 6, 7, 8, and 9). The tissues of the exposed group showed the presence of type II, type III, and type IV nucleoids along with the presence of type 0 and type 1 nucleoids. The cells having type 0 and type I nucleoids are considered as undamaged cells, while the cells having type II, type III, and type IV nucleoids are considered as damaged.
In all the tissues, as the exposure period increased, the number of cells showing type II, type III, and type IV nucleoids increased. The gill and liver showed maximum damage in type IV damaged cells where complete DNA was in tail, i.e., the length of DNA comet tail was very long where the head of the nucleus was very small. The kidney and blood showed the type IV DNA damage where the DNA comet tail length was long, but here, the head of the nucleus was distinctly visible.

Percentage (\%) of DNA damage in fish increased significantly in all the tissues as the days of exposure increased (Table 5). \% of DNA damage was calculated by taking into account the number of nucleoids in type II + type III + type IV. Least DNA damage was seen in the tissues of control group (Fig. 10). All the tissues showed maximum DNA damage on the 21 st day. \% of DNA damage in tissues after 21 days of exposure was $\mathrm{G}>\mathrm{B}>\mathrm{L}>\mathrm{K}$.

The genetic damage index (GDI) was found to be least in all the tissues in the control group (Fig. 11). The GDI was highest in all tissues on the 21st day of exposure, i.e., as the days of exposure increased, GDI increased significantly (Table 6). The GDI was highest on the 21st day in $\mathrm{G}>\mathrm{B}>\mathrm{L}>\mathrm{K}$.

\section{Concentration of DNA}

The total DNA content in $1 \mu \mathrm{l}$ of sample was calculated for all the tissues in control group, $24 \mathrm{~h}$ exposure, 7 days exposure, 14 days exposure, and 21 days exposure using Nano Drop ND-100 at 260/280 nm (Fig. 12 and Table 7).

Table $\mathbf{5} \%$ of DNA damage in tissues of C. carpio on exposure to karanjin

\begin{tabular}{llllll}
\hline Tissue/exposure & Control & $24 \mathrm{~h}$ & 7 days & 14 days & 21 days \\
\hline Gill & $4 \pm 0.89$ & $7.33 \pm 1.86^{*}$ & $25 \pm 5.43^{*}$ & $39.16 \pm 4.87^{*}$ & $46.16 \pm 4.35^{*}$ \\
Liver & $4.33 \pm 1.03$ & $11.16 \pm 1.16^{*}$ & $21.33 \pm 2.87^{*}$ & $32.66 \pm 2.5^{*}$ & $44.33 \pm 3.98^{*}$ \\
Kidney & $5.16 \pm 1.72$ & $9.33 \pm 1.5^{*}$ & $24.16 \pm 2.31^{*}$ & $30.66 \pm 2.5^{*}$ & $39 \pm 3.34^{*}$ \\
Blood & $3.83 \pm 1.47$ & $11.5 \pm 1.87^{*}$ & $23.83 \pm 4.87^{*}$ & $33.83 \pm 3.76^{*}$ & $45 \pm 4.42^{*}$ \\
\hline
\end{tabular}

Values are expressed as mean \pm standard deviation ${ }^{*} P<0.05$ 


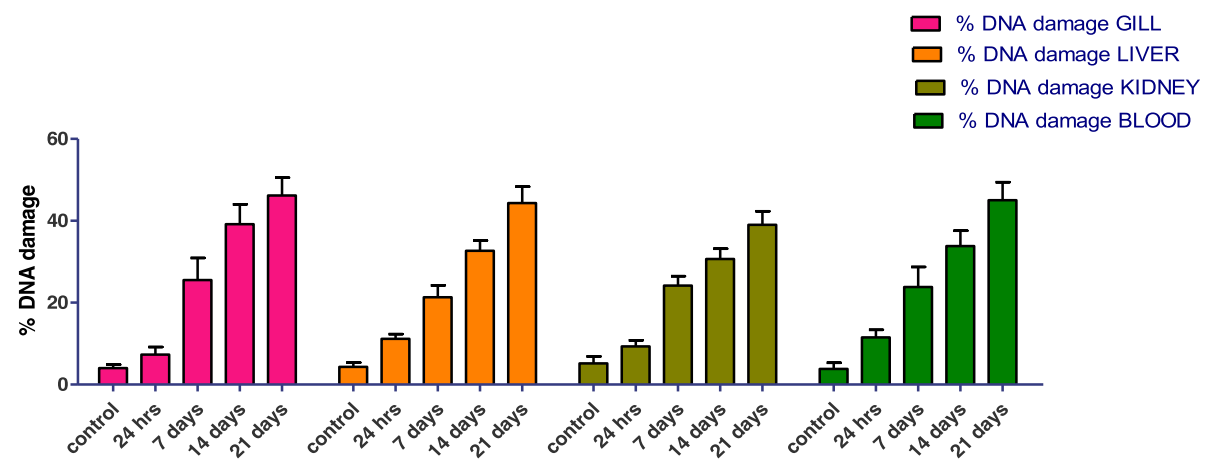

Fig. $10 \%$ of DNA damage in tissues of C. carpio during sub-lethal exposure to karanjin

The amount of DNA is thus represented as nanograms per microliter of sample. The amount of DNA was found to be highest in the liver followed by the kidney, the blood, and least found in the gills, i.e., liver > kidney $>$ blood $>$ gill. All the tissues of control group fishes showed higher amount of DNA while the tissues of exposed group fishes showed significant decrease $(P<0.05)$ in the amount of DNA as the exposure period increased, throughout the completion of 21 days of sub-lethal exposure to karanjin (Table 5 and Fig. 9). These results are also in agreement with the gel doc images of gels having the DNA samples of the gill, liver, kidney, and blood of control group and exposure groups (Figs. 13, 14, 15, and 16). The reason for the decrease in the DNA content in all the tissues during sub-lethal exposure to karanjin may be due to the decrease in protein synthesis, defective nucleic acid metabolism, degradation of cells, inhibition of enzymes useful in replication of DNA, loss of cell structure, proliferation of new cells, formation of new tissue, and tissue degradation. Whenever there is DNA damage, the process of DNA repair mechanism also under process in a cell. The presence of karanjin or any other pesticide slows down the DNA repair mechanism.

\section{Discussion}

In the present study, observable reduction of optical density was induced by karanjin when compared with control. Fish are one of the most important aquatic organisms in any aquatic ecosystem as they play many roles in the trophic web; they respond directly to very low concentrations of toxic substances which are present in the water and also respond indirectly by feeding on contaminated aquatic organisms (Cavas \& ErgeneGözükara, 2005; Sasaki et al., 1997). Hence, fish can be used as biomarkers for early detection of contamination of an aquatic ecosystem. Pesticides form the important group of compounds concerning pollution of water bodies. Fish are best indicators of pesticide pollution in an aquatic environment due to the fact that their metabolic state changes frequently in response to pesticides (Begum, 2004; Cattaneo et al., 2011). Various species of

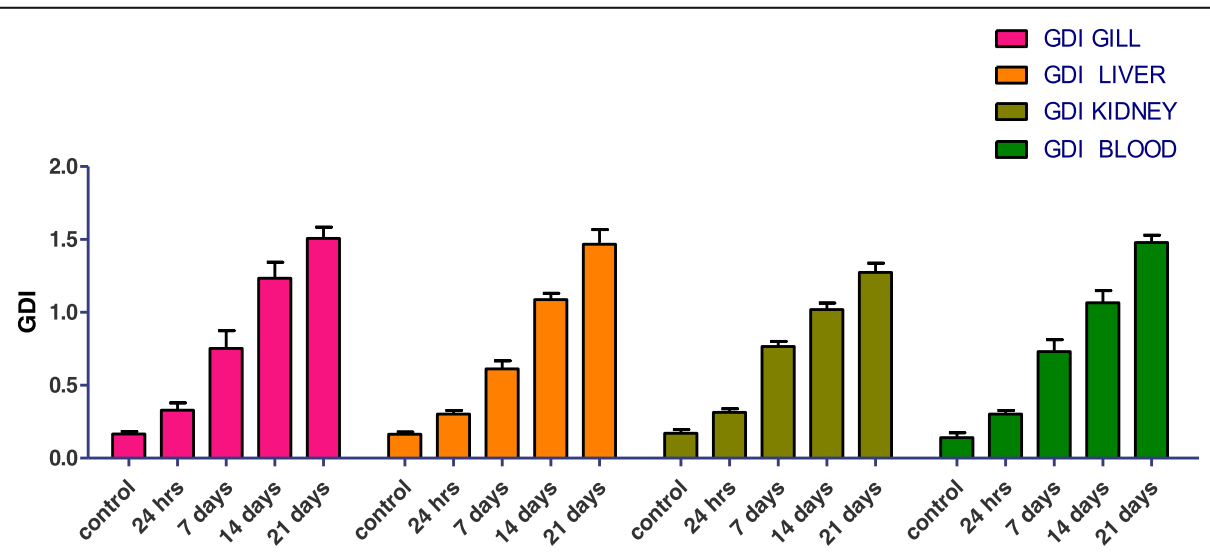

Fig. 11 Genetic damage index (GDI) in the tissues of C. carpio during sub-lethal exposure to karanjin 
Table 6 Genetic damage index (GDI) in tissues of C. carpio on exposure to karanjin

\begin{tabular}{llllll}
\hline Tissue/exposure & Control & $24 \mathrm{~h}$ & 7 days & 14 days & 21 days \\
\hline Gill & $0.16 \pm 0.01$ & $0.32 \pm 0.05^{*}$ & $0.75 \pm 0.12^{*}$ & $1.23 \pm 0.11^{*}$ & $1.5 \pm 0.07^{*}$ \\
Liver & $0.16 \pm 0.01$ & $0.3 \pm 0.02^{*}$ & $0.61 \pm 0.05^{*}$ & $1.08 \pm 0.04^{*}$ & $1.46 \pm 0.1^{*}$ \\
Kidney & $0.17 \pm 0.02$ & $0.31 \pm 0.02^{*}$ & $0.76 \pm 0.03^{*}$ & $1.01 \pm 0.04^{*}$ & $1.27 \pm 0.06^{*}$ \\
Blood & $0.14 \pm 0.03$ & $0.3 \pm 0.02^{*}$ & $0.73 \pm 0.08^{*}$ & $1.06 \pm 0.08^{*}$ & $1.47 \pm 0.05^{*}$ \\
\hline
\end{tabular}

Values are expressed as mean \pm standard deviation

${ }^{*} P<0.05$

freshwater and marine fishes have been used as models for genotoxicity testing in aquatic environments.

DNA strand breaks are measured by the comet assay which is an important biomarker of genotoxicity in fish (Mitchelmore \& Chipman, 1998). Comet assay is widely used, simple, and sensitive technique for evaluating in vivo, in vitro, and in situ DNA damage in different tissues of fish such as gill, liver, kidney, and blood after exposure to different kinds of pollutants of aquatic environment (Dhawan, Bajpayee, \& Parmar, 2009). The readily available and easy to collect tissue in fish is blood: $97 \%$ of total fish blood comprises of RBCs. Hence, $\mathrm{RBCs}$ are frequently used in fish to evaluate DNA damage by the comet assay method. Solid tissues such as gill, liver, and kidney require cell dissociation and isolation before proceeding with the comet assay procedure using such methods that themselves do not cause DNA damage. The comet assay under alkaline condition can identify DNA damage of different kinds such as single-strand breakage, alkaline labile sites, and DNA cross-links that are induced by pesticides (Kumar, Nagpure, Kwshwaha, Srivastava, \& Lakra, 2010; Tice et al., 2000). Comet assay has considerable advantages over the other cytogenetic methods because in this method, the cells do not require to be mitotically dividing. (Ali et al., 2009; Ali \& Kumar, 2008; Nwani et al., 2010) stated that the higher DNA damage in cells of the gills could be due to the reason that gills are constantly exposed to the pollutants of water that may cause DNA damage whereas RBCs come in contact with the pollutants only after circulation.
Most of the toxic substances that produce genotoxicity have been found to produce reactive oxygen species as well as electrophilic free-radical metabolites that interact with the DNA and lead to its disruption. Studies conducted by Chandra and Khuda-Bukhsh (2004) and Klopman, Conttreras, Reosenkranz, and Waters, (1985) showed that during the metabolism of azadirachtin, electrophilic ions and free radicals are produced, which interact with the nucleophilic sites in DNA and lead to breaks and other related DNA damage. It is also reported that the oxidative stress in an organism plays an important role to inducing cytotoxicity and genotoxicity in different vital tissues (Moore, Yedjou, \& Tchounwou, 2010).

Time-dependent increase in DNA damage has been observed in the present study. The DNA damage observed in the present study can be correlated with the findings of (Cavas \& Konen, 2007) on the blood cells of Carassius auratus exposed to glyphosate. Blood and gill cells of Prochilodus lineatus showed DNA damage on exposure to glyphosate (Cavalcante, Martinez, \& Sofia, 2008). DNA damage in the blood cells of Oreochromis mossambicus increased as the heavy metal concentration increased (Ahmed et al., 2011). (Kousar \& Javed, 2015) also reported DNA damage in RBC's of four fish species, showed an increase as the days of exposure to heavy metal increased. Large comet tails of DNA were seen in erythrocytes of Cobitis elongate on exposure to industrial effluents (Kopjar et al., 2008). Cd and Al showed genotoxic potential to zebra fish Danio rerio (Pereira, Cavalie,

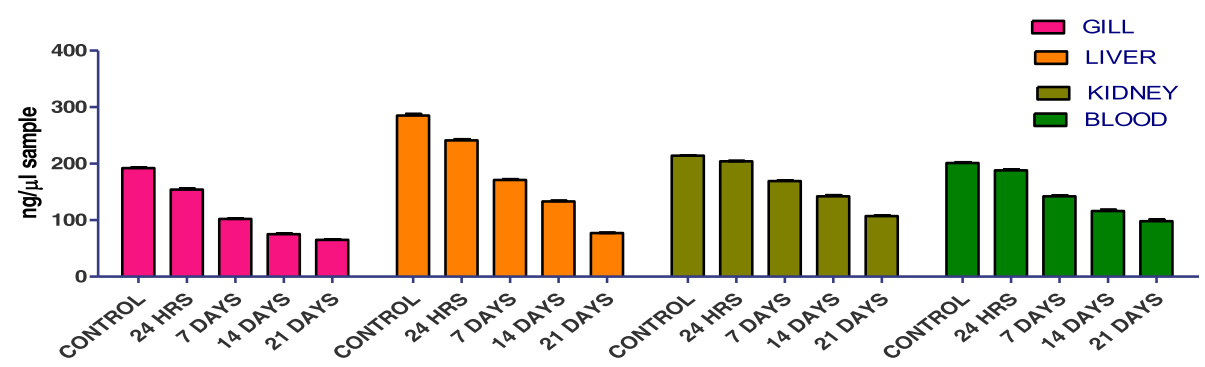

Fig. 12 DNA content in tissues of C. carpio, on exposure to karanjin 
Table 7 Total DNA content $(\mathrm{ng} / \mathrm{\mu l})$ in the gill, liver, kidney, and blood in the fish Cyprinus carpio during exposure to sub-lethal concentration of karanjin

\begin{tabular}{llllll}
\hline Tissue & Control & $24 \mathrm{~h}$ exposure & 7 days exposure & 14 days exposure & 21 days exposure \\
\hline Gill & $192 \pm 0.89$ & $154 \pm 1.41^{*}$ & $102 \pm 0.63^{*}$ & $75 \pm 1.09^{*}$ & $65 \pm 1.26^{*}$ \\
Liver & $285 \pm 2.82$ & $241 \pm 2^{*}$ & $171 \pm 1.61^{*}$ & $133 \pm 1^{*}$ & $77 \pm 0.44^{*}$ \\
Kidney & $214 \pm 0.31$ & $204 \pm 0.7^{*}$ & $169 \pm 1.3^{*}$ & $142 \pm 2^{*}$ & $107 \pm 1^{*}$ \\
Blood & $201 \pm 1.43$ & $188 \pm 1.41^{*}$ & $142 \pm 1.41^{*}$ & $116 \pm 2.28^{*}$ & $98 \pm 2.82^{*}$ \\
\hline
\end{tabular}

Values are expressed as mean \pm standard deviation ${ }^{*} P \leq 0.05$

Camilleri, Gilbin, \& Adam-Guillermin, 2013). Results observed in the present study can be compared with those of (Kousar \& Javed, 2014) where red blood cells of carps showed significant $(P<0.05)$ DNA damage due to heavy metals. A study performed by Matsumoto et al. (2006) showed significant increase in DNA damage in the peripheral blood erythrocytes of Oreochromis niloticus exposed to chromium. The results of the present studies are in agreement with the finding of Kumar et al. (2010) which proved that malathion can cause DNA damage in Channa punctatus. Common carp when exposed for 3 days to a textile dye effluent showed DNA damage, which was measured using comet assay (Sumathi, Kalaiselvi, Palanviel, \& Rajaguru, 2001).

Nucleic acid content of an organism is considered as an index of capacity of protein synthesis. The development and growth of the fishes depend upon the content of DNA which serve as important biochemical parameter (Buckley, 1980). Active protein synthesis and cell growth are dependent on the DNA content. Whenever an organism is exposed to pesticide-dissolved water, its nucleic acid content changes. (Ansari \& Kumar, 1988) have reported a significant decrease in the DNA content of liver of zebra fish, Danio rerio, on exposure to cypermethrin. A significant decline in the DNA content in Labeo rohita on exposure to ammonia was observed by Acharya, Dutta, and Das (2005). Maruthanayagam and Sharmila (2004) conducted studies on the effect of monocrotophos on Cyprinus carpio and concluded that the pesticide leads to several changes in DNA which may be due to the increased activity of the enzyme DNase function.

Significant reduction in DNA content in different organs of fish exposed to karanjin in the present investigation may be due to decrease in protein synthesis, defective nucleic acid metabolism, and also degradation of cells. Another important reason for DNA damage may be the inhibition of enzymes that replicate or repair DNA ( Singh et al., 1988; Aruoma, Halliwell, Gajewski, \& Dizdaroglu, 1991; Guilherme, Santos, Barroso, Gaivao, \& Pacheo, 2012). The intactness of the DNA is the important part of the normal cellular process. The changes in DNA may be due to loss of cell structure, proliferation of new cells, formation of new tissue, and tissue degradation (Youson, 1988) which ultimately results in total loss of cellular control mechanism (Heath, 1998). Many pesticides have been proven to induce changes in DNA (Massimo, Milena, Scassellati, \& Rossana, 2000; Vrhovae \& Zeljezic, 2000) and structural changes at the level of chromosomes (Mathur, 1988). The physiochemical interaction of the pesticides with the cellular DNA produces a number of primary changes such as singlestrand breaks, double-strand breaks, DNA protein crosslink, and damage to purine and pyrimidine bases (Van Loon, Groenendijk, Van Der Shcanslohman, \& Bran, 1991). Similar results were also reported by various

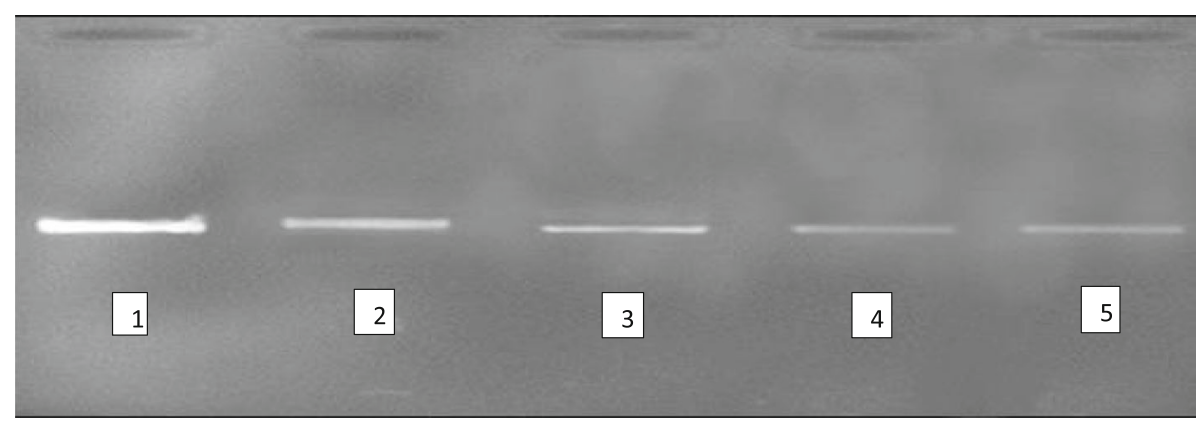

Fig. 13 Gel image showing DNA of the gill 


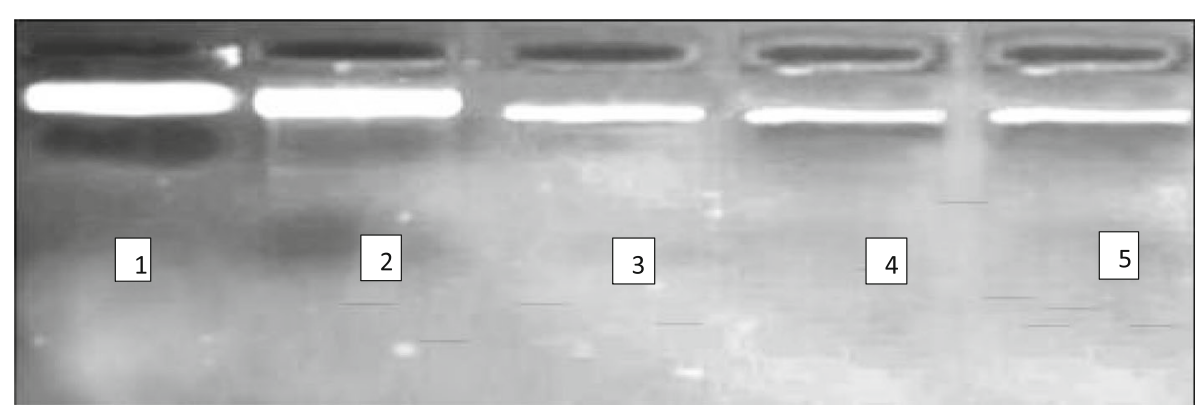

Fig. 14 Gel image showing DNA of the liver

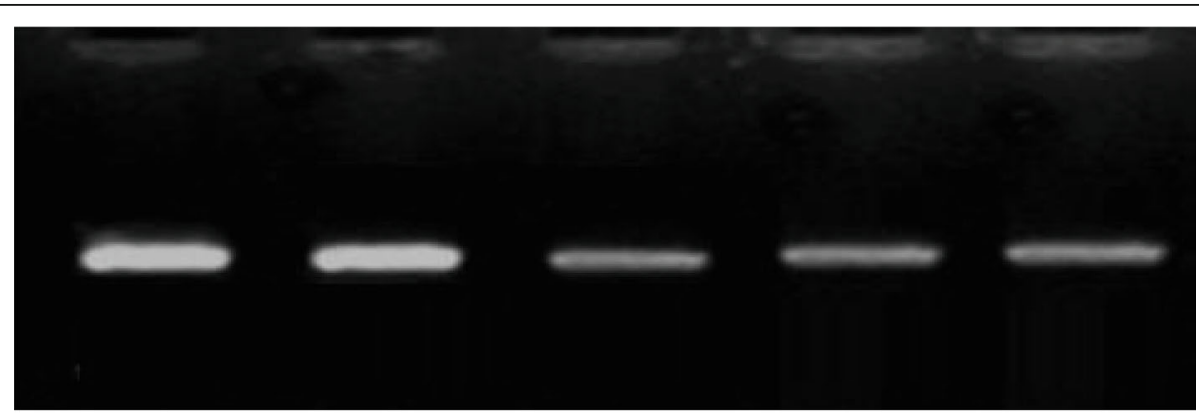

Fig. 15 Gel image showing DNA of the kidney

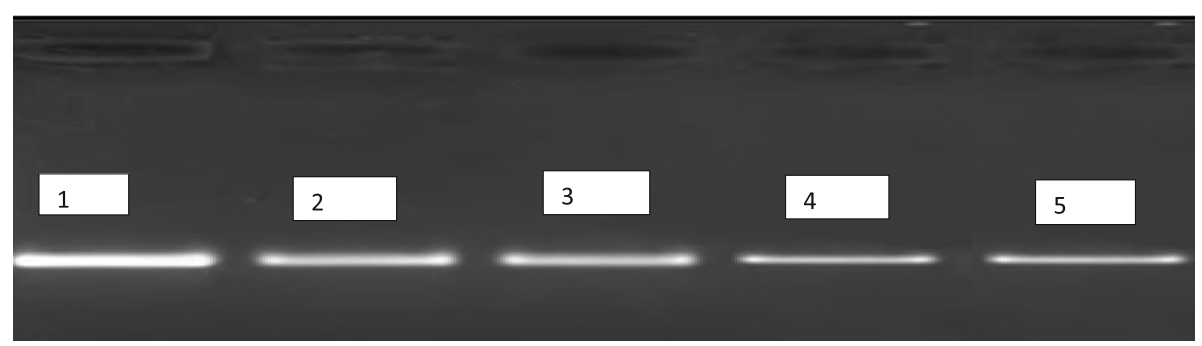

Fig. 16 Gel image showing DNA of the blood 
investigations: Cyprinus carpio (Gowri, Govindassamy, \& Ramalingam, 2013), Cirrhinus mrigala (Veeraiah, Vivek, Srinivas Rao, \& Venkatrao, 2013), Channa punctatus (Thakur \& Kakde, 2012), Labeo rohita (Tiwari, Tiwari, \& Singh, 2012), Colisa lalia (Singh, Singh, \& Yadav, 2010), Cirrhinus mrigala (Vasantharaja, Pugazhendy, Meenaambai, Prabukaran, \& Dar, 2013), Channa striatus (Raksheskar, 2012), Channa punctatus (Kumar, Sharma, \& Pandey, 2007), and Cyprinus carpio (Ansari \& Kumar, 1988). Channa punctatus is exposed to methanol (Tiwari \& Singh, 2003).

\section{Conclusion}

In conclusion, the results of the present study indicate that the comet assay or alkaline SCGE is a very sensitive test showing clear response of an organ or tissue towards dose and exposure period. Comet assay has many advantages over other types of commonly used assays in that it can be used to assess the genotoxicity in a wide range of organisms, in different types of tissues. Karanjin, though a plant secondary metabolite derived from plant, caused genotoxicity in the common carp Cyprinus carpio during sub-lethal exposure, and also, the total DNA content in gill, liver, kidney, and blood decreased as the days of exposure increased. Hence, comet assay or SCGE is preliminary and the best assay to assess genotoxicity in any organism and any kind of tissue.

\section{Abbreviations}

\%: Percentage; B: Blood; DNA: Deoxyribose nucleic acid; EDTA: Ethylenediaminetetraacetic acid; EtBr: Ethidium bromide; G: Gill; K: Kidney; L: Liver; LC: Lethal concentration; LM Agarose: Low-melting agarose; SCGE: Single-cell gel electrophoresis; UV: Ultraviolet

\section{Acknowledgements \\ The authors are very thankful to the Department of Zoology for providing the research facilities. The work done in this paper is a part of the Ph.D. work of ST. The authors give their sincere thanks to Prof. K. Venkaiah, HOD, Dept. of Statistics, NIN-Hyd, for helping us with the statistical analysis of the data. ST is also immensely thankful to Mr. Sankeshi Venu for his kind help in carrying out the work relating to comet assay. Shoeiba Tasneem is immensely thankful to the UGC-Maulana Azad National Fellowship scheme for the financial assistance throughout the research period.}

\section{Competing of interests}

The authors declare that they have no competing interests.

\section{Funding}

We declare that there are no funding sources.

\section{Availability of data and materials}

All the data and materials presented in the manuscript are the original work of the authors.

\section{Authors' contributions}

ST designed the work and performed the experiment. ST and RY have written the manuscript. Both the authors read and approved the manuscript.

\section{Ethics approval and consent to participate}

The present study was conducted in accordance with the guidelines of IAEC (Institutional Animal Ethical Committee), and approval was taken in order to perform the experiments.

\section{Consent for publication}

We give our consent to The Editor of The Journal of Basic and Applied Zoology (Springer) that our manuscript be published in their journal.

\section{Publisher's Note}

Springer Nature remains neutral with regard to jurisdictional claims in published maps and institutional affiliations.

Received: 27 November 2017 Accepted: 20 February 2018 Published online: 06 March 2018

\section{References}

Acharya, S., Dutta, T., \& Das, M. K. (2005). Influence of sub lethal ammonia toxicity on some physiological parameters of Labeo rohita (Hamilton-Buchanan) fingerlings. Journal of Environmental Biology, 26(4), 615-620.

Ahmed, M. K., Habibullah-Al-Mamun, M., Hossain, M. A., Arif, M., Parvin, E., Akter, M. S., ... Islam, M. M. (2011). Assessing the genotoxic potentials of arsenic in tilapia (Oreochromis mossambicus) using alkaline comet assay and micronucleus test. Chemosphere, 84, 143-149.

Al Muqarrabun, L. M., Ahmat, N., Ruzaina, S. A., Ismail, N. H., \& Sahidin, I. (2013). Medicinal uses, phytochemistry and pharmacology of Pongamia pinnata (L.) Pierre: a review. Journal of Ethnopharmacology. https://doi.org/10.1016/j.jep. 2013.08.041.

Ali, D. \& Kumar, S. (2008). Long-term genotoxic effect of monocrotophos in different tissues of freshwater fish Channa punctatus (Bloch) using alkaline single cell gel electrophoresis. Science of the Total Environment, 405(1-3), 345350

Ali, D., Nagpure, N. S., Kumar, S., Kumar, R., Kushwaha, B., \& Lakra, W. S. (2009). Assessment of genotoxic and mutagenic effects of chlorpyrifos in freshwater fish Channa punctatus (Bloch) using micronucleus assay and alkaline singlecell gel electrophoresis. Food and Chemistry Tox, 47(3), 650-656.

Anderson, D., Yu, T. W., Phillips, B., \& Schezer, P. (1994). The effect of various antioxidants and other modifying agents on oxygen radical-generated DNA damage in human lymphocytes in the comet assay. Mutation Research, 307, $261-271$

Andrade, V. M., Freitas, T. R. O., \& Silva, J. (2004). Comet assay using mullet (Mugil sp.) and catfish (Netuma sp.) erythrocytes for the detection of genotoxic pollutants in aquatic environment. Mutation Research, 560, 57-67.

Anis Joseph, R., Premila, K. S., Nisha, V. G., Rajendran, S., \& Sarika Mohan, S. (2010). Safety of neem products to tetragnathid spiders in rice ecosystem. Journal of Biopesticides, 3(1), 88-89.

Ansari, B. A., \& Kumar, K. (1988). Cypermethrin toxicity: effect on the carbohydrate metabolism of the Indian catfish, Hetropneustes fossilis. Science of the total environment, 72, 161-166.

Ansari, B. A., \& Sharma, D. K. (2009). Toxic effect of synthetic pyrethroid deltamethrin and neem based formulation Achook on zebrafish, Danio rerio. Trends in Biosciences, 2, 18-20.

Aruoma, O. I., Halliwell, B., Gajewski, E., \& Dizdaroglu, M. (1991). Copper ion dependent damage to the bases in DNA in the presence of $\mathrm{H} 2 \mathrm{O} 2$. Journal of Biochemistry, 273, 601-604.

Begum, G. (2004). Carbofuran insecticide induced biochemical alterations in liver and muscle tissues of the fish Clarias batrachus (linn) and recovery response. Aquatic Toxicology, 66, 83-92.

Belpaeme, K., Delbeke, K., Zhu, L., \& Kirsch-Volders, M. (2004). Cytogenetic studies of PCB77 on brown trout (Salmo trutta fario) using the micronucleus test and the alkaline comet assay. Mutagenesis, 5, 485-492.

Buckley, L. J. (1980). Changes in ribonucleic acid, deoxyribonucleic acid and protein content during ontogenesis in winter flounder, Psedopleuronectes americanus and effect of starvation. Fishery Bulletin, 77, 703-708.

Cattaneo, R., Clasen, B., Loro, V. L., de Menezes, C. C., Pretto, A., Baldisserotto, B., . De Avila, L. A. (2011). Toxicological responses of Cyprinus carpio exposed to a commercial formulation containing glyphosate. Bulletin of Environmental Contamination and Toxicology, 87, 597-602.

Cavalcante, D. G. M., Martinez, C. B. R., \& Sofia, S. H. (2008). Genotoxic effects of roundup on the fish Prochilodus lineatus. Mutation Research, 655, 41-46.

Cavas, T., \& Ergene-Gözükara, S. (2005). Induction of micronuclei and nuclear abnormalities in Oreochromis niloticus following exposure to petroleum refinery and chromium processing plant effluents. Aquatic Toxicology, 74, 264-271.

Cavas, T., \& Konen, S. (2007). Detection of cytogenetic and DNA damage in peripheral erythrocytes of gold fish (Carassius auratus) exposed to glyphosate 
formulation using the micronucleus test and comet assay. Mutagenesis, 22, 263-268.

Chandra, P., \& Khuda-Bukhsh, A. R. (2004). Genotoxic effects of cadmium chloride and azadirachtin treated singly and in combination in fish. Ecotoxicology and Environmental Safety, 58, 194-201.

Collins, A. R. (2004). The comet assay for DNA damage and repair: principles, applications and limitation. Molecular Biotechnology, 26, 249-260.

Dhawan, A., Bajpayee, M., \& Parmar, D. (2009). Comet assay: a reliable tool for the assessment of DNA damage in different models. Cell Biology and Toxicology, $25,5-32$.

Gowri, B., Govindassamy, P., \& Ramalingam, V. (2013). Influence of cypermethrin on DNA and RNA content in different organs of freshwater fish Cyprinus carpio. Iranian Journal of Pharmaceutical Sciences, 9(3), 1-10.

Grover, P., Danadevi, K., Mahboob, M., Rozati, R., Saleha, B., \& Rahman, M. F. (2003). Evaluation of genetic damage in workers employed in pesticide production utilizing the comet assay. Mutagenesis, 18, 201-205.

Guilherme, S., Santos, M. A., Barroso, C., Gaivao, I., \& Pacheo, M. (2012). Differential genotoxicity of roundup formulation and its constituents in blood cells of fish (Anquilla anquilla): considerations on chemical interactions and DNA damaging mechanisms. Ecotoxicology, 21, 1381-1390.

Hartman, A. Schumacher, M., Plappert-Helberg, U., Lowe, P., Suter, W., \& Mueller, L. (2004). Use of the alkaline in vivo comet assay for mechanistic genotoxicity investigations. Mutagenesis, 19, 51-59. https:/doi.org/10.1093/mutage/ geg038.

Heath, A. G. (1998). Physiology and ecological health. In J. J. Cech, B. W. Wilson, \& D. G. Gosby (Eds.), Multiple stresses in ecosystem, (pp. 59-89). Washington DC: Lewis Publishers.

Istvan, U. (2000). Semi-natural products and related substances as alleged botanical pesticides. Pest Management Science, 56, 703-705.

Karunamoorthi, K. (2012). Medicinal and aromatic plants: a major source of green pesticides/risk-reduced pesticides. Med Aromat Plants, 1, 137.

Kim, S. I., Yoon, J. S., Jung, J. W., Hong, K. B., Ahn, Y. J., \& Known, H. W. (2010). Toxicity and repellency of Origanum essential oil and its components against Tribolium castaneum (Coleoptera: Tenebrionidae) adults. Journal of Asia Pacific Entomology., 13, 369-373.

Kleinjans, J. C. S., \& Van Schooten, F. J. (2002). Ecogenotoxicology: the evolving field. Environmental Toxicology and Pharmacology, 11, 173-179.

Klopman, G., Conttreras, R., Reosenkranz, H. S., \& Waters, M. D. (1985). Structuregenotoxic activity relationships of pesticides: comparison of the results from several short-term assays. Mutation Research, 147, 343-356.

Kopjar, N., Mustafic, P., Zanella, D., Buj, I., Caleta, M., Marcic, Z., ... Mrakovcic, M. (2008). Assessment of DNA integrity in erythrocytes of Cobitis elongate affected by water pollution: the alkaline comet assay study. Folia Zoologica, $57(1-2), 120-130$

Kousar, S., \& Javed, M. (2014). Assessment of DNA damage in peripheral blood erythrocytes of fish exposed to arsenic under laboratory conditions. International Journal of Current Microbiology and Applied Sciences, 3(11), 877-888.

Kousar, S., \& Javed, M. (2015). Diagnosis of metals induced DNA damage in fish using comet assay. Pakistan Veterinary Journal, 35(2), 168-175.

Kracun-Kolarevic, M., Kolarevic, S., Jovanovic, J., Markovic, V., llic, M., Simonovic, P., ... Vukovic-Gacic, B. (2016). Evaluation of genotoxic potential throughout the upper and middle stretches of Adige river basin. Science of the Total Environment., 571, 1383-1391.

Kumar, A., Sharma, B., \& Pandey, R. S. (2007). Preliminary evaluation of the acute toxicity of cypermethrin and $\lambda$-cyhalothrin to Channa punctatus. Bulletin of Environmental Contamination and Toxicology, 79, 613-616.

Kumar, R., Nagpure, N. S., Kwshwaha, B., Srivastava, S. K., \& Lakra, W. S. (2010). Investigation of the genotoxicity of malathion to freshwater teleost fish Channa punctatus (Bloch) using the micronucleus test and comet assay. Archives of Environmental Contamination and Toxicology, 58, 123-130.

Lemos, N. G., Dias, A. L., Silva-Souza, A. T., \& Mantovani, M. S. (2005). Evaluation of environmental waters using the comet assay in Tilapia rendalli. Environmental Toxicology and Pharmacology, 19, 197-201. https://doi.org/10.1016/j.etap. 2004.03.011.

Liao, W., McNutt, M. A., \& Zhu, W. (2009). The comet assay: a sensitive method for detecting DNA damage in individual cells. Methods, 48, 46-53.

Lopez, M. D., Jordan, M. J., \& Pascual-Villalobos, M. J. (2008). Toxic compounds in essential oils of coriander, caraway and basil active against stored rice pests. Journal of stored products Research., 44, 273-278.

Majumdar, D. (2002). Suppression of nitrification and N2O emission by karanjin - a nitrification inhibitor prepared from karanja (Pongamia glabra Vent.) Chemosphere, 47, 845-850.
Majumdar, D., Pandya, B., Arora, A., \& Dhara, S. (2004). Potential use of karanjin (3-methoxy furano-2', 3', 7, 8-flavone) as a nitrification inhibitor in different soil types. Archives of Agronomy and Soil Science, 50, 455-465.

Maruthanayagam, C., \& Sharmila, G. (2004). Biochemical variations induced by monocrotophos in Cyprinus carpio during the exposure and recovery period. Nature, Environment and Pollution Technology, 3(1), 1-9.

Massimo, M., Milena, V., Scassellati, S. G., \& Rossana, P. (2000). Pesticide induced primary DNA damage in peripheral blood leucocytes of farm workers evaluated by the computerized comet assay. Biomarkers, 5, 192-204.

Mathur, P. C. (1988). Pesticides industry in India. Pesticides Information, 23, 17-29.

Matsumoto, S. T., Mantovani, M. S., Malaguttii, M. I. A., Dias, A. U., Fonseca, V., \& Morales, M. A. (2006). Genotoxicity and mutagenicity of water contaminated with tannery effluents, as evaluated by the micronucleus test and comet assay using the fish Oreochromis niloticus and chromosome aberrations in onion root-tips. Genetics and Molecular Biology, 29, 148-158.

Mitchelmore, C. L., \& Chipman, J. K. (1998). Detection of DNA strand breaks in brown trout (Salmo trutta) hepatocytes and blood cells using the single cell gel electrophoresis (comet) assay. Aquatic Toxicology, 41, 161-182.

Mitkovska, V. I., Dimitrov, H. A., \& Chassovnikarova, T. G. (2017). In vitro genotoxicity and cytotoxicity assessment of allowable concentrations of nickel and lead: comet assay and nuclear abnormalities in acridine orange stained erythrocytes of common carp (Cyprinus carpio L.) Acta Zoologica Bulgarica, 8, 47-56.

Moore, P. D., Yedjou, C. G., \& Tchounwou, P. B. (2010). Malathion-induced oxidative stress, cytotoxicity and genotoxicity in human liver carcinoma (HepG2) cells. Environmental Toxicology, 25(3), 221-226.

Nwani, C. D., Lakra, W. S., Nagpure, N. S., Kumar, R., Kushwaha, B., \& Sirvastava, S K. (2010). Mutagenic and genotoxic effects of carbosulfan in freshwater fish Channa punctatus (Bloch) using micronucleus assay and alkaline single-cell gel electrophoresis. Food and Chemical Toxicology, 48(1), 202-208.

Palus, J., Dziubaltowska, E., \& Rydzynski, K. (1999). DNA damage detected by the comet assay in the white blood cells of workers in a wooden furniture plant. Mutation Research, 444, 61-74.

Pavela, R. (2009). Larvicidal property of essential oils against Culex quinquefasciatus say (Diptera: Culicidae). Industrial Crops and Products, 30, 311-315.

Pereira, S., Cavalie, I., Camilleri, V., Gilbin, R., \& Adam-Guillermin, C. (2013). Comparative genotoxicity of aluminum and cadmium in embryonic zebrafish cells. Mutation Research, 750, 19-26.

Pitarque, M., Creus, A., Marcos, R., Hughes, J. A., \& Anderson, D. (1999). Examination of various biomarkers measuring genotoxic endpoints from Barcelona airport personnel. Mutation Research, 440, 195-204.

Raksheskar, G. A. (2012). Influence of cypermethrin on DNA, RNA and RNA/ DNA ratio in gills of the freshwater fish Channa striatus. Bioscience Discovery, 3, 17-19.

Salem, Z. B., Capelli, N., Grisey, E., Baurand, P.-E., Ayadi, H., \& Aleya, L. (2014). First evidence of fish genotoxicity induced by heavy metals from landfill leachates: the advantage of using the RAPD-PCR technique. Ecotoxicology and Environmental Safety, 101, 90-96.

Sambrook, J., Fritsch, E. F., \& Maniatis, T. (1989). Molecular cloning: A laboratory manual, (2nd ed., ). New York: Cold Spring Harbor Laboratory.

Sasaki, Y. F., Izumiyama, F., Nishidate, E., Ishibashi, S., Tsuda, S., Matsusaka, N., ... Hayashi, M. (1997). Detection of genotoxicity of polluted sea water using shellfish and the alkaline single-cell gel electrophoresis (SCE) assay: a preliminary study. Mutation Research, 393, 133-139.

Singh, K. S., Singh, S. K. S., \& Yadav, R. P. (2010). Toxicological and biochemical alterations of cypermethrin (synthetic pyrethroid) against freshwater teleost Colisa fasciatus at different seasons. World Journal of Zoology, 5(7), 25-32.

Singh, N. P., McCoy, M. T., Tice, R. R., \& Schneider, E. L. (1988). A simple technique for quantification of low levels of DNA damage in individual cells. Experimental Cell Research, 175, 184-191.

Sumathi, M., Kalaiselvi, K., Palanviel, M., \& Rajaguru, P. (2001). Genotoxicity of textile dye effluent on fish (Cyprinus carpio) measured using the comet assay. Bulletin of Environmental Contamination and Toxicology, 66, 407-414. https://doi.org/10.1007/s00128-001/0020-3.

Tamrakar, A. K., Yadav, P. P., Tiwari, P., Maurya, R., \& Srivastava, A. K. (2008). Identification of pongamol and karanjin as lead compounds with antihyperglycemic activity from Pongamia pinnata fruits. Journal of Ethnopharmacology, 118, 435-439.

Thakur, A. C., \& Kakde, V. R. (2012). Influence of cypermethrin on DNA, RNA and RNA/DNA ratio in muscles of the freshwater fish Channa punctatus. International Interdisciplinary Research Journal, 2, 38-42. 
Tice, R. R., Agurell, E., Anderson, D., Burlinson, B., Hartmann, A., Kobayashi, H., ... Sasaki, Y. F. (2000). Single cell gel/comet assay: guidelines for in vitro and in vivo genetic toxicology testing. Environmental and Molecular Mutagenesis, 35(3), 206-221.

Tiwari, S., \& Singh, A. (2003). Metabolic changes in the snake head fish, Channa punctatus due to lattices of Euphorbia royleana. Asian Fisheries Science, 16, 147155.

Tiwari, S., Tiwari, R., \& Singh, A. (2012). Impact of cypermethrin on fingerlings of common edible carp (Labeo rohita). The Scientific World Journal, 1, 1-7.

Van Loon, A. A. W. M., Groenendijk, R. H., Van Der Shcanslohman, P. H. M., \& Bran, R. A. (1991). Detection of induced damage in DNA in human blood exposed to ionic radiation at biologically relevant doses. International Journal of Radiation Biology, 59, 651-660.

Vasantharaja, C., Pugazhendy, C., Meenaambai, M., Prabukaran, S., \& Dar, N. A. (2013). Properties of Cardiospermum halicacabum against the toxic effect of cypermethrin in the quantification of nucleic acids in the freshwater fish Cirrhinus mrigala (Hamilton). International Research Journal of Pharmacy, 4(1), 280-283.

Veeraiah, K., Vivek, C., Srinivas Rao, P., \& Venkatrao, G. (2013). Biochemical changes induced by cypermethrin (10\% EC), a pyrethroid compound in sublethal and lethal concentrations to the freshwater fish Cirrhinus mrigala (Hamilton). J. Atom. Mol, 3(6), 625-634.

Vethanayagam, S. M., \& Rajendran, S. M. (2010). Bioefficacy of neem insecticidal soap (NIS) on the disease incidence of bhendi, Abelmoschus esculentus (L.) Moench under field conditions. Journal of Biopesticides, 3(1), 246-249.

Vrhovae, G. V., \& Zeljezic, D. (2000). Evaluation of DNA damage in workers occupationally exposed to pesticide using SCG assay. Pesticides genotoxicity revealed by comet assay. Mut. Res., 469, 279-285.

WHO (2003). Traditional Medicine, "Neem Tree/Neem oil", Fact Sheet No. 134 (). Geneva: WHO

Youson, J. H. (1988). First metamorphosis. In W. S. Hoar, \& D. J. Randall (Eds.), Fish Physiol, (vol. II). New York: Academic Press.

\section{Submit your manuscript to a SpringerOpen ${ }^{\circ}$ journal and benefit from:}

- Convenient online submission

- Rigorous peer review

- Open access: articles freely available online

- High visibility within the field

- Retaining the copyright to your article

Submit your next manuscript at $\gg$ springeropen.com 